\title{
Konstruksi Islam sebagai Simbol Identitas melalui Representasi Perempuan Muslim pada Novel Religi
}

\author{
Husnan Nurjuman, Uliviana Restu, dan Bayu Teja Kususma \\ Universitas Sultan Ageng Tirtayasa \\ Email: husnan.nurjuman@untirta.ac.id
}

\begin{abstract}
This paper describes the construction of the practice of Islam as a symbol of group identity in the midst of the reality of society through the representation of Muslim women in the Queen's Religion prostrate novel. This research with a qualitative approach to semiotic analysis from Roland Barthes describes the text with denotative, connotative and mythical systematics. The novel Ratu yang Bersujud which prostrates presents the Islamic concept of Muslim women in the form of protection and breeding for women, the primacy of the role of women in the household, women as male partners and equality of men and women. Representation of the concept of muslim women is part of Islamic construction as a group identity. The construction of reality as a result of the interaction between the writer and the reality of Islamic thought, the reality of women's progress, the reality of the negative stigma of western civilization towards Islam, and the reality of symbolic trends in religious life, which is then disignified in novel texts, and internalized by society. The results of this study become an illustration of the reality of trends in society that make the understanding of Islam about the position of women as representations of identity, through cultural products, in the form of religious novels. The findings and analysis can be an illustration of the process of intervention in social change, including interventions that are da'wah framed. Propagators can use cultural products as a medium or means to internalize various thoughts in Islam into a reality constructed in the community.
\end{abstract}

Keywords: Islam; Identity; Construction

\section{ABSTRAK}

Tulisan ini menggambarkan konstruksi pengamalan Islam sebagai simbol identitas kelompok di tengah realitas masyarakat melalui representasi perempuan muslim pada novel religi Ratu yang Bersujud. Penelitian dengan pendekatan kualitatif analisis semiotika dari Roland Barthes ini menguraikan teks dangan sistematika denotatif, konotatif dan mitos. Novel Ratu yang Bersujud yang bersujud menghadirkan konsep Islam tentang perempuan muslim berupa perlindungan dan pemuliaan bagi perempuan, keutamaan peran perempuan dalam rumah tangga, perempuan sebagai mitra laki-laki dan kesetaraan laki-laki dan perempuan. Representasi konsep perempuan muslim merupakan bagian dari konstruksi Islam sebagai identitas kelompok. Konstruksi realitas sebagai hasil interaksi antara penulis dengan realitas pemikiran Islam, realitas kemajuan perempuan, realitas stigma negatif peradaban barat terhadap Islam, serta realitas tren simbolik kehidupan beragama, yang kemudian disignifikasi dalam teks-teks novel, dan diinternalisasi oleh masyarakat. Hasil penelitian ini menjadi gambaran tentang realitas tren di masyarakat yang menjadikan paham agama Islam tentang posisi perempuan sebagai representasi identitas, 
melalui produk budaya, berupa novel religi. Hasil temuan dan analisis ini dapat menjadi gambaran bagi proses intervensi dalam perubahan sosial, termasuk dalam intervensi yang berbingkai dakwah. Para pelaku dakwah dapat menggunakan produk budaya sebagai media atau sarana dalam menginternalisasikan berbagai pemikiran dalam Islam menjadi realitas yang dikonstruksi di tengah masyarakat.

Kata kunci : Islam, Identitas, Konstruksi

\section{PENDAHULUAN}

Konstuksi realitas sosial adalah proses yang senantiasa simultan dan berlanjut, dalam tahapan eksternalisasi, objektivasi dan internalisasi (Berger dan Luckmann, dalam Bungin, 2008). Tiap hasil konstruksi akan berinteraksi dengan individu dan masyarakat yang melakukan eksternalisasi yang kemudian melanjutkan proses konstruksi realitas selanjutnya. Maka tiap pengulangan siklus konstruksi tersebut akan membuka terjadinya konstruksi yang baru.

Pemahaman terhadap Islam dan ajaran Islam telah menjadi realitas dalam kesadaran pemeluknya. Kesadaran tersebut juga terbangun dari proses dialektik konstruksi realitas sosial. Pemeluk agama Islam bereksternalisasi dengan berinteraksi tidak hanya melalui produk-produk paham atau pemikiran agama Islam yang terus berkembang dan mengandung pemikiran baru, tapi juga berhadapan dengan realitas perkembangan peradaban yang silih berganti dari era kejayaan Islam dan masa kegelapan Eropa, sampai dengan era modern, bahkan paska modern. Ojektivasi terbangun ketika ketika para pemeluk agama Islam yang telah bereksternalisasi itu melembagakan kesadaran mereka menjadi kesadaran bersama baik dalam bentuk kelompok, tatanan sosial, pranata yang juga mewujud dalam simbol dan bahasa. Selanjutnya tiap individu dalam komunitas tersebut berinternalisasi dengan mengidentifikasikan dirinya berdasarkan kesadaran yang dibangun oleh simbol tersebut.

Interaksi antara pemikiran Islam yang berkembang dengan realitas yang terjadi di tengah peradaban manusia telah mengkonstruksi suatu kesadaran tentang kehidupan beragama. Pada fase awal, agama Islam dikonstruksi sebagai ajaran yang secara substansi dibahasakan sebagai ajaran berupa perintah, larangan dan petunjuk pembawa keselamatan bagi manusia baik di dunia dan akhirat (Majelis Tarjih PP.Muhammadiyah, 2009). Islam dikonstruksi sebagai kumpulan petunjuk bagi orang beriman agar mereka menjalankan hidupnya sehingga dapat mencapai keluhuran harkat manusia. Ketika tatanan masyarakat Islam sudah terbangun, maka proses eksternalisasi, objektivasi dan internalisasi memunculkan konstruksi realitas agama Islam sebagai suatu sistem atau institusi yang lengkap dengan produk hukum, norma, budaya dan struktur. Agama dipahami dan diamalkan sebagai hukum dan lembaga yang tersimbolkan dengan istilah halal, haram, wajib, sunnah, khalifah dan sebagainya. Dalam bahasa lain hal itu disebut dengan Islam Syari'at (Nashir, 2007)

Dalam penelitian terdahulu tentang konstruksi media Islam mengenai 
pemikiran pluralisme dalam Islam (Nurjuman, 2006), perbedaan konstruksi itu diisitilahkan dengan polarisasi dua kelompok yaitu Islam secara substansi dan Islam secara institusi. Islam substansi menjadi istilah yang mewakili konstruksi Islam sebagai nilai dan ajaran. Sedangkan konstruksi tentang Islam sebagai lembaga dan aturan dibahasakan dengan Islam institusi. Perkembangan kehidupan beragama di Indonesia masa kini (terutama setelah 2005) telah menampakkan suatu konstruksi realitas yang baru. Era reformasi yang telah membawa nuansa kebebasan berkespresi memberikan perubahan pada kehidupan spiritual masyarakat Indonesia, khususnya masyarakat pemeluk agama Islam. Kebebasan tersebut telah memberikan ruang bagi masyarakat mengeskpresikan simbolsimbol keberagamaan mereka.

Pada masa ini, agama, termasuk Islam, tidak dikenalkan dengan bahasa tentang halal, haram, wajib, sunnah dan lain sebagainya. Masyarakat membangun konstruksi agama sebagai pedoman yang bertujuan memanusiakan manusia, membawa manusia pada kemuliaan derajatnya. Ajaran tentang shalat dipahami sebagai jalan mencegah kekejian dan kemunkaran. Ajaran tentang menutup aurat dibahasakan sebagai cara memuliakan perempuan. Teks Qur'an tentang poligami dikonstruksi sebagai cara untuk memaslahatkan kehidupan masyarakat dan rumah tangga dengan bertumpu pada azas keadilan. Pada masa konstruksi ini, perempuan muslim telah direpresentasikan dalam sosok figur yang menjadi tempat penyematan nilai-nilai Islam tentang perlindungan perempuan, keutamaan posisi perempuan, perempuan sebagai penolong (mitra) laki-laki. Nilai-nilai tersebut disandarkan pada tonggak-tonggak dasar ajaran Islam dan kehidupan yang dicontohkan oleh para penyebar ajaran. Kehidupan beragama tidak lagi sebatas internalisasi terhadap paham agama dari objektivasi yang mereka lalui, tapi telah jauh melampaui menjadi budaya populer dan tren yang berkembang.

Dalam Penelitian tentang kekuasaan budaya populer religiotaiment dalam pengemasan acara dakwah di televisi (Nurjuman dan Sakinah, 2012), dinarasikan bahwa acara siraman rohani Islam telah dikemas sedemikian rupa menjadi acara yang mencampurkan antara dakwah dan hiburan yang berorientasi pada rating televisi. Budaya pengajian lokal dan dakwah di masyarakat muslim sebagai internalisasi paham keberagamaan telah berkembang menjadi tren budaya populer yang glamour dengan kegiatan entertainment dan simbol-simbol yang tidak lagi askestis, seperti arisan, seragam majelis ta'lim, wisata religi, umroh bersama artis, tahajud bersama di hotel berbintang dan lain sebagainya. Pada penelitian yang berjudul kesalehan simbolik hijab style sebagai budaya konsumen (Nurjuman, Nursih dan Sakinah, 2014), pemakaian jilbab di kalangan perempuan muslim juga tidak lagi menjadi ukuran dari internalisasi pemahaman hukum dan ajaran agama Islam, melainkan telah menjadi simbolisasi kesalehan sebagai identitas dan tren sekaligus juga menggiring pada perangkap dunia industri dalam bentuk budaya konsumen.

Berbagai fenomena tersebut, telah membangun suatu kerangka pemikiran, 
bahwa Islam telah mengalami suatu bentuk konstruksi yang baru. Islam tidak lagi hanya dikonstruksi sebagai nilai dan ajaran (Islam substansi) atau sebagai hukum dan sistem (Islam institusi) tapi juga telah terbangun sebagai kesadaran tentang identitas yang diwujudkan daam tren kesalehan simbolik. Pengamalan nilai, ajaran, norma dan aturan Islam telah menjadi identitas kelompok yang menuntut adanya suatu simbolisasi.

Kajian tentang konstruksi Islam sebagai nilai dan ajaran (Islam substansi) atau sebagai hukum dan sistem (Islam institusi) dipaparkan dalam penelitian tesis Husnan Nurjuman yang diterbitkan Unversitas Indonesia (Nurjuman, 2006), Penelitian tersebut merupakan analisis framing terhadap teks majalah Sabili dan Majalah Syir'ah tentang tema pluralisme. Kedua majalah tersebut membingkai isu pluralisme berdasarkan konstruksi realitas mereka masing-masing tentang agama dan Islam. Majalah Sabili cenderung mengkonstruksi agama sebagai institusi, hukum, dan sistem sehingga isu pluralisme dipandang sebagai hal yang berada di luar sistem tersebut, sebagai suatu hal baru dan berbahaya. Berbeda dengan Syir'ah yang lebih mengkonstruksi agama sebagai nilai, sehingga pluralisme dipandang sebagai sesuatu yang menjembatani nilai -nilai yang sama pada agama yang berbeda - beda.

Sedangkan kajian tentang konstruksi agama sebagai simbol identitas (Nurjuman dan Sakinah, 2012) dan kesolehan simbolik hijab style sebagai budaya konsumen (Nurjuman, Wasingah, dan Sakinah, 2014) mengungkapkan fenomena tentang budaya populer yang berkembang di masyarakat, yang terkait dengan kehidupan beragama. Agama dilihat sebagai hal yang berkembang menjadi tren dan simbol identitas yang diaktualisasikan dalam berbagai kegiatan, termasuk dalam program acara dakwah televisi dan dalam gaya busana berjilbab. Program acara dakwah televisi tidak lagi sekedar kegiatan belajar masyarakat tentang agama, tapi menjadi kegiatan pertunjukan yang populer dengan berbagai pengemasannya. Pengenaan busana jilbab bagi muslimah tidak lagi sekedar pengamalan ajaran menutup aurat, tapi sebagai kegiatan populer yang direpresentasikan dalam berbagai gaya yang mewah serta budaya belanja yang konsumtif. Kedua penelitian tersebut mengidentifikasi budaya populer dalam kegiatan agama sebagai bentuk simbolisasi kesolehan atau kesalehan simbolik (Ibrahim, 2011) yang dalam penelitian ini, kesalehan simbolik itu dikaji sebagai bagian dari suatu proses konstruksi realitas agama sebagai simbol identitas.

Penelitian yang melatari artikel ini membangun asumsi bahwa simbolisasi Islam pada praktik kehidupan sehari-hari sebagai wujud dari proses konstruksi sosial yang berlangsung di masyarakat. Hal baru yang coba dikembangkan dalam penelitian ini bawah kemudian masyarakat menginterkasikan antara symbolsymbol religious islam baik berupa ajaran, maupun teks-teks tentang ajaran dengan berbagai kegoatan dan produksi produk-produk budaya kehidupan sehari-hari. Penelitian ini mengkaji novel religi sabagai salah satu produk yang dihasilkan dari interaksi antara teks ajaran dan produk budaya populer menjadi konstruksi agama 
sebagai simbol identitas.

Simbolisasi Islam sebagai identitas tidak hanya mewujud pada praktik kehidupan pengamalan Islam sehari-hari, tapi juga hadir dalam produk-produk budaya seperti lagu, film dan novel. Hal tersebut ditandai dengan masifnya musikmusik bernuansa religi mewarnai dunia hiburan Indonesia. Tidak hanya oleh artis yang memang sejak awal telah mengembangkan kesenian Islam, tapi juga artisartis lain yang sama sekali tidak pernah bersentuhan sebelumnya degan aktivitas keagamaan. Dunia perfilman Indonesia juga diramaikan oleh para sineas yang menghasilkan karya-karya yang religius. Tren budaya ini merupakan wujud pembacaan para seniman terhadap adanya kecenderungan kesadaran khalayak tentang nilai, ajaran, norma dan hukum Islam sebagai identitas kelompok.

Objek penelitian ini adalah sebuah novel dengan judul Ratu yang Bersujud. Novel ini merupakan karya seorang penulis dengan nama pena Mahdavi. Novel yang diterbitkan pada bulan Januari 2013 ini bercerita tentang pergulatan batin seorang perempuan dalam memahami agama Islam dan pandangan Islam terhadap perempuan. Novel ini berusaha menyampaikan berbagai pandangan Islam tentang perempuan yang selama ini dipandang konvensional, kolot dan mengekang perempuan secara lebih moderat, yang kemudian memunculkan berbagai diskusi dan kritik mengenai bagaimana perempuan Islam berperan dalam kehidupan personal dan sosialnya. Hal yang juga menarik untuk dilihat dalam novel ini adalah kenyataan bahwa Mahdavi adalah laki-laki, sehingga diskusi, kritik dan pergulatan yang terjadi dalam novel ini bersumber dari sudut pandang seorang "laki-laki".

Penelitian ini tidak lagi sebatas membicarakan perempuan dalam konteks representasi berbagai varian pemikiran Islam, baik Islam yang konservatif, moderat maupun liberal. Penelitian ini menempatkan representasi perempuan muslim dalam novel religi sebagai wujud simbolisasi agama dalam karya -karya sastra. Bukan sekedar membahas apakah novel ini menyampaikan paham Islam tentang permpuan, tapi representasi perempuan muslim adalah simbolisasi Islam dalam aktivitas dan produk budaya populer.

Novel Ratu yang Bersujud memunculkan berbagai pertanyaan yang mencoba mengorek pandangan Islam mengenai perempuan di tengah maraknya isu gender dan feminisme. Pertanyaan yang seringkali muncul adalah tentang mengapa wanita harus memakai jilbab? mengapa wanita harus mengurusi rumah tangga? bagaimana kedudukan wanita di dalam Islam?. Berbagai pertanyaan tersebut menjadi kunci yang mempertentangkan antara peradaban Islam dan peradaban modern. Pertanyaan yang menjadi representasi benturan antara peradaban modern dan Islam (Saefullah, 2007) . Jawaban dari pertanyaan-pertanyaan tersebut menjadi representasi pemikiran Islam yang dikonstruksi tidak hanya sebagai ajaran dan pelembagaan paham keagamaan, tapi juga menjadi identitas kelompok muslim di tengah kancah hegemoni globalisasi dan modernisasi.

Novel Ratu Yang Besujud memperlihatkan penggambaran perempuan dari sudut pandang pemikiran Islam yang dikosntruksi berdasarkan pemahaman 
penulis novel terhadap ajaran Islam. Penulis novel berusaha untuk menggambarkan sosok perempuan dengan menempatkan sang tokoh perempuan sebagai sosok perempuan yang ingin mendapakan emansipasi, kesetaraan dan juga derajat yang sama dengan laki-laki. Kisah perjuangan sosok perempuan dalam novel ini menjadi menarik ketika novel ini dikemukakan di tengah perbenturan budaya dan peradaban antara Islam dan dunia modern, sehingga konstruksi yang dibangun tidak hanya mewujud sebagai konstruksi pemahaman Islam sembagai ajaran (substansi) atau lembaga (sistem dan norma), tapi juga sebagai simbol identitas.

Tulisan ini merupakan uraian analitis terhadap suatu konstruksi tentang perempuan muslim pada sebuah novel berjudul Ratu yang Bersujud. Tulisan ini didasarkan pada penelitian yang mengembangkan kajian tentang kehidupan beragama yang diekspresikan dan dinteraksikan melalui simbol-simbol identitas kelompok, baik yang berwujud pada budaya populer seperti religiotaiment di televisi maupun budaya konsumen seperti pada isu hijab style. Hal lain yang coba digambarkan melalui tulisan ini adalah bagimana simbol-simbol identitas kehidupan beragama tersebut mewujud dalam satu produk budaya, yang hadir di tengah perbenturan peradaban Islam dan barat, khususnya pada isu gender.

Tulisan ini bertujuan untuk menggambarkan konstruksi tentang pemahaman Islam sebagai simbol identitas kelompok di tengah realitas masyarakat melalui representasi perempuan muslim pada novel religi. Diharapkan penelitian ini dapat memberikan kontribusi bagi perkembangan kajian sosiologi komunikasi dan fenomena dakwah melalui implementasi teori konstruksi realitas sosial pada fenomena kehidupan beragama khususnya agama Islam dan lebih khusus lagi pada isu kesetaraan gender.

Penelitian ini menggunakan pendekatan kualitatif. Unit analisis pada penelitian ini adalah teks yang terdapat pada beberapa bab novel Ratuyang Bersujud. Metode analisis yang dipergunakan dalam penelitian ini adalah metode penelitian semiotika Roland Barthes yang menguraikan teks dangan sistematika denotatif, konotatif dan mitos, sebuah metode yang dikembangkanoleh Barthes antara tahun 1950 - 1970 yang (Hoed, 2011). Selanjutnya analisis dilakukan berdasarkan teori konstruksi realitas sosial Berger dan Luckmann (1966).

\section{HASIL DAN PEMBAHASAN}

Konstruksi realitas sosial merupakan preses terbentuknya suatu realitas pengetahuan melalui suatu proses interaksi sosial. Realitas adalah sesuatu hal yang sebenarnya diinternalisasikan oleh atau melalui suatu proses sosial (Berger \& Luckmann, 1966: 196). Proses konstruksi atas realitas terjadi dalam siklus eksternalisasi, objektivasi dan internalisasi yang terus terjadi secara berulang. Ketiga tahapan tersebut merupakan dialektika yang terus menghasilkan suatu kesadaran atau konstruksi. Namun dialektika tersebut terus berulang dan secara 
simultan menghadirkan realitas yang dikonstruksi. Pengulangan (siklis) seperti pertemuan antara tesis dengan antitesis menjadi sintesis. Kemudian sintesis berubah menjadi tesis kedua yang akan bertemu dengan antitesis yang baru lalu membentuk sintesis yang kedua, dan begitu selanjutnya.

Novel dengan judul Ratu yang Bersujud merupakan novel karya seorang penulis dengan nama pena Mahdavi. Novel ini berkisah tentang sosok Charllotte Melati Neumuller, seorang gadis keturunan Jerman-Indonesia yang pada awal cerita digambarkan sebagai seorang feminis sejati yang begitu gigih membela kepentingan kaum perempuan dan beranggapan bahwa agama Islam adalah agama yang melakukan diskriminasi terhadap perempuan. Namun setelah kehadiran sepupunya Lale, kebencian Charlotte berubah menjadi ketakjuban, dan dia memutuskan untuk memeluk agama Islam dan menggunakan nama Islam "Chadijah Maryam". Charlotte yang sebelumnya berada di kubu kaum feminis menjadi berada di kubu muslim. Bersama Lale, mereka menyampaikannya dan menyosialisasikan berbagai pandangan Islam tentang perempuan yang selama ini dipandang konvensional, kolot dan mengekang perempuan. Mereka menampilkan sisi moderat dari pemikiran Islam yang menunjukkan bahwa Islam sangat menghargai perempuan dan menempatkannya pada posisi yang mulia.

Kajian terhadap novel Ratu yang Bersujud yang kemudian dipertemukan dengan diskusi tentang siklis konstruksi realitas sosial dan kajian tentang agama sebagai simbol identitas telah menghasilkan beberepa temuan penelitian. Antara lain 1) representasi pemikiran islam tentang perempuan muslim, 2) mitos tentang perempuan muslim dan pemikiran islam moderat, 3) representasi perempuan muslim dalam siklis konstruksi realitas, dan 4) konstruksi islam sebagai simbol melauai representasi perempuan muslim. Keempat temuan tersebut merupakan hasil kajian secara berurutan dan saling melengkapi yang dimulai dengan telaah teks semiotika terhadap novel Ratu yang Bersujud yang kemudian ditarik dalam telaah konteks dan latar konstruksi realitas agama sebagai simbol identitas yang menjadi bagian dari siklis konstruksi realitas sosial tentang agama.

Representasi pemikiran Islam tentang Perempuan muslim merupakan hasil kajian atas makna denotasi dan konotasi pada berbagai teks novel yang merepresentasikan pemikiran Islam tentang perempuan. Sedangkan mitos perempuan muslim dalam pemikiran Islam moderat merupakan paparan tentang pokok - pokok pikiran Islam moderat tentang perempuan yang telah menjadi andangan dan pandangan serta opini yang lazim disepakati di masyarakat yang menjadi latar atau lingkungan pembuatan novel tersebut.

Sedangkan representasi perempuan muslim dalam siklis konstruksi realitas adalah pembahasan hasil analisis teks dalam prespektif teori konstruksi sosial realitas Peter L. Berger yang diidentifikasi dengan eksternalisasi, objektivasi dan internalisasi. Selanjutnya hasil kajian tersebut didiskusikan lagi dengan kajian kehodupan beragama tentang fenomena konstruksi Islam sebagai simbol identitas. 


\section{Representasi Pemikiran Islam tentang Perempuan Muslim}

Berdasarkan telaah yang dilakukan terhadap berbagai teks atau kalimat pada novel Ratu yang Bersujud melalui analisis semiotika, ditemukan identifikasi representasi perempuan muslim dalam makna denotasi dan makna konotasi. Kedua kategori makna tersebut mencoba menunjukan upaya yang dilakukan penulis novel untuk menghadirkan konsep perempuan muslim menurut pemahaman sang penulis terhadap ajaran Islam tentang perempuan.

Konsep perempuan muslim yang direpresentasikan didalam novel ratu yang bersujud ini antara lain: pertama, memakai hijab bagi perempuan sebagai representasi pemuliaan dan perlindungan. Novel Ratu yang Bersujud mengambarkan konsep perempuan yang ideal dalam Islam adalah perempuan yang saleh dalam artian taat beragama, termasuk dalam hal menutup aurat. Novel ini menggambarkan bahwa dalam Islam, hijab adalah pakaian wajib bagi perempuan karena hijab memang difungsikan sebagai penutup aurat dan juga sebagai bentuk perlindungan diri. Hal tersebut sebagaimana tergambar dalam salah satu teks novel berikut :

Tabel 1. Pemakaian Hijab

\begin{tabular}{ll}
\hline Teks & $\begin{array}{l}\text { "Hijab adalah pembebasan dari ketergantungan kosmetik dan topeng. } \\
\text { Hijab adalah pembebasan untuk jujur pada hatimu. Hijab adalah pembebas } \\
\text { jiwamu dari rantai-rantai duniawi." }\end{array}$ \\
Makna & $\begin{array}{l}\text { Pemakaian Hijab merupakan proses untuk bebas dari ketergantungan pada } \\
\text { kosmetik yang merupakanbagian dari rantai - rantai duniwai (hedonism } \\
\text { dan industri) }\end{array}$ \\
Makna & Hijab adalah bentuk pemuliaan dan perlindungan perempuan. \\
Konotasi & \\
Mitos & $\begin{array}{l}\text { Hijab lazim di pandang sebagai atribut yang digunakan oleh perempuan } \\
\text { muslim untuk mencirikan } \\
\text { ketaatannya terhadap ajaran Islam. } \\
\text { Hijab saat ini dikaitkan dengan tren fashion lebih daripada simbol agama. }\end{array}$ \\
\hline
\end{tabular}

Tabel 1 menggambarkan tentang pemaknaan terhadap salah satu bagian dari novel Ratu yang Bersujud yang menujukan tentang konstruksi penulis tentang hijab bagi perempuan muslim. Tabel 1 menunjukkan bagaimana penulis mencoba mengkonstruksi hijab sebagai bentuk pemuliaan dan perlindungan bagi perempuan. Perlindungan bagi perempuan tersebut tidak hanya diidentifikasi sebagai penjagaan atas posisi perempuan terhadap dominasi kaum pria yang menjadikan perempuan sebagai objek. Tapi juga perlindungan terhadap perempuan dari dominasi dunia industri, kapitalism yang mewujud dalam tren fashion dan kosmetik.

Hal tersebut juga ditunjukkan dengan teks yang menyatakan hijab sebagai pembebasan dari ketergantungan kosmetik dan topeng. Pada teks ini, kosmetik tidak dianggap sebagai penyempurna penampilan perempuan tapi sebagai topeng yang membelenggu kemurnian dan kebebasan perempuan itu sendiri. Penulis 
novel melihat bahwa perempuan menggunakan kosmetik sebagai upaya untuk menyembunyikan kondisi sebenarnya, kondisi alamiah yang seharusnya menjadi daya tarik utamanya. Opini penulis novel mengenai hal ini cukup menarik (atau menjadi sebuah ironi) karena berasal dari sudut pandang laki-laki (Mahdavi, penulis adalah laki-laki), yang secara umum seringkali dianggap hanya melihat kecantikan lahiriah seorang perempuan, atau dengan kata lain mudah tertarik dengan perempuan yang cantik. Dalam berbagai iklan atau promo kosmetik, kehadiran sosok perempuan cantik dan laki-laki yang jatuh cinta pada perempuan tersebut menjadi sangat lumrah ditemui. Tidak hanya sosok laki-laki, berbagai bentuk kesuksesan juga diperlihatkan dapat diraih apabila perempuan tersebut cantik. Tentunya visualisasi semacam ini membentuk persepsi kuat dalam benak perempuan bahwa untuk menjadi perempuan ya harus cantik, jika tidak cantik maka akan tersisih dalam lingkaran sosial masyarakat.

Kedua, peran perempuan sebagai pemimpin dalam rumah tangga sebagai representasi keutamaan peran perempuan. Perempuan dalam Islam digambarkan dalam novel mempunyai peran penting dan utama. Seperti pada kalimat yang menyatakan bahwa dalam peran tersebut wanita merupakan seorang pemimpin "seorang perempuan (istri) adalah pemimpin dan harus bertanggung jawab terhadap rumah tangga yang dipimpinnya", dilihat dari konteks kalimatnya bahwa perempuan berkewajiban untuk menjadi pemimpin dalam urusan rumah tangga, sudah jelas bahwa urusan rumah tangga adalah urusan yang wajib dilakukan oleh perempuan.

Tabel 2. Perempuan Pengatur Rumah Tangga

\begin{tabular}{cl}
\hline Teks & "Oh iya Lale, tapi bagaimana islam mengatur peran perempuan, misalkan \\
& dalam urusan rumah tangga. Tidak adakah peran mereka, selain melahirkan \\
& anak?" charlotte begitu cerdas sehingga ia selalu saja mendapatkan bahan \\
& pertanyaan. Otaknya memang sangat kritis. "Tolong simak, ya, Melati. Aku \\
& akan menyampaikan sebuah hadits yang akan langsung menjawab \\
& pertanyaan kamu." "Setiap kaum adalah pemimpin, dan setiap pemimpin \\
& harus bertanggung jawab terhadap apa yang dipimpinnya. Seorang kepala \\
& Negara adalah pemimpin dan ia harus bertanggung jawab terhadap \\
& rakyatnya, seorang laki - laki (suami) adalah pemimpin dan harus \\
& bertanggung jawab terhadap keluarga yang dipimpinnya, seorang \\
& perempuan (istri) adalah pemimpin dan harus bertanggung jawab terhadap \\
& rumah tangga yang dipimpinnya." \\
Makna & Seorang perempuan (istri) adalah pemimpin dan harus bertanggung jawab \\
Denotasi & terhadap rumah tangga yang dipimpinnya. \\
Makna & Perempuan memiliki kutamaan dengan peran yang strategis mengatur \\
Konotasi & urusan rumah tangga \\
Mitos & Perempuan sama dengan istri. Predikat ini melekat dan dengannya maka \\
& perempuan dianggap "wajib" mengurus rumah tangga dan suami. \\
& Walaupun ia dibebaskan bekerja di luar rumah, kewajiban tersebut tetap \\
& melekat dan menjadi sebuah faktor utama yang mengindikasikan \\
& kesuksesannya sebagai perempuan.
\end{tabular}


Tabel 2 mengambarkan tentang konstruksi penulis Ratu yang Bersujud tentang keutamaan perempuan dalam kehidupan rumah tangga. Teks yang ditulis dalam novel merupakan ungkapan yang mengutip suatu adits tentang tiap orang adalah pemimipin, dan tiap pemimpin akan dimintai pertanggungjawaban. Ketika hadits tersebut menyatakan tiap orang, penulis novel mengkonstruks bahwa yang disebut tiap orang itu adalah juga termasuk perempuan yang dalam budaya serngkali diamanati tugas sebagai pengurus rumah tangga. Maka makna denotasi yang dimunculkan dari teks tersebut dapat dilihat bahwa perempuan adalah pemimpin dalam mengelola urusannya di bidang domestik rumah tangga. Maka pemaknaan perempuan sebagai pemimpin dapat dimaknai lebih lanjut sebagai pemaknaan keutamaan perempuan sebagai pemimpin.

Ketiga, Perempuan sebagai mitra laki-laki sebagai representasi kesetaraan perempuan dan laki-laki. Novel Ratu yang Bersujud ini juga menggambarkan bagaimana hubungan dan hak bagi perempuan dalam islam seperti di dalam kalimat "Dan orang orang yang beriman, lelaki dan perempuan, sebagian mereka (adalah) menjadi penolong bagi sebagian yang lain". Charlotte menunggu penjelasan Lale. "Kau tahu Melati, kata penolong menurut sebagian ulama dapat mencakup kerjasama, bantuan, dan penguasaan. Setelah menguraikan hasil penelitian perlu analisis dengan menambahkan teori atau referensi yang sesuai. Konsep ini juga ditegaskan dalam salah satu teks novel seperti yang digambarkan pada tabel berikut :

Tabel 3. Perempuan sebagai Mitra Laki -Laki

\begin{tabular}{cl}
\hline Teks & "Oh ya bagaimana islam memandang hubungan antara laki - laki dan \\
& perempuan lale. Kudengar kultur masyarakat islam dan arab, begitu \\
& merendahkan kaum perempuan. Kau punya jawaban untukku?" akhirnya \\
& pembicaraan antara charlotte dan lale mengarahkan charlotte untuk \\
& mengungkap tanya kembali. Lale tersenyum. Ia tahu charlotte hari ini akan \\
& menuju ke titik yang lebih tinggi lagi dalam pencariannya. "aku akan \\
& membacakan sebuah terjemahan untukmu. Dan orang orang yang \\
& beriman, lelaki dan perempuan, sebagian mereka (adalah) menjadi \\
& penolong bagi sebagian yang lain. Mereka menyuruh (mengerjakan) yang \\
& makruf, mencegah dari yang munkar, melaksanakan sembahyang, \\
& menunaikan zakat, dan mereka taat kepada Allah dan Rasul-Nya. Mereka \\
& itu akan diberi rahmat oleh Allah, sesungguhnya Allah Mahaperkasa lagi \\
& Mahabijaksana." Charlotte menunggu penjelasan Lale. "Kau tahu Melati, \\
& kata penolong menurut sebagian ulama dapat mencakup kerjasama, \\
& bantuan, dan penguasaan. Hal ini dapat disimpulkan dalam konteks mitra, \\
& antara lelaki dan perempuan." \\
Makna & Penggambaran melalui terjemahan Alquran mengenai hubungan antara laki \\
Denotasi & - laki dan perempuan yang saling melengkapi \\
Makna & Dalam Islam tidak ada perbedaan dalam hal hubungan antara laki - laki \\
Konotasi & dan perempuan.
\end{tabular}




$\begin{array}{ll}\text { Mitos } & \text { Perempuan di rumah dan laki-laki bekerja. Pandangan ini lazim dianut oleh } \\ \text { masyarakat, dan banyak dipengaruhi oleh kebiasaan setempat. Masyarakat } \\ \text { modern memiliki pandangan yang berbeda dan melihat perempuan pun } \\ \text { mampu bekerja di luar rumah dan memiliki karir yang tinggi, akan tetapi } \\ \text { tetapi peran di rumah tetap mayoritas dibebankan pada perempuan (istri). }\end{array}$

Konstruksi lain yang dikemukakan oleh penulis novel yang tergambar dalam tabel 3 adalah perempuan sebagai mitra laki - laki. Penulis Novel melalui figur Charlote mencoba membantah tuduhan pihak luar Islam terutama dunia barat modern yang membawa stigma bahwa Islam merendahkan perempuan. Tuduhan tersebut dijawab dengan teks novel yang mengutip salah satu pesan ajaran agama Islam bawah tiap muslim adalah penolong bagi muslim lainnya. Kalimat ini dapat dimaknai bahwa posisi seseorang atau sekelompok orang sebagai penolong bagi orang atau kelompok lainnya menunjukkan posisi setara yang saling bekerjasama. Maka teks tersebut mengandung makna, yang jika dikaitkan dengan relasi antara laki - laki dan perempuan muslim, maka posisi mereka adalah setara untuk saling menolong dan bekerjasama. Maka Penulis novel melalui teks ini mencoba mengkontruksi bahwa Islam memandang hubungan laki - laki dan prempuan sebagai mitra dan melepaskan stigma masyarakat terhadap peran domestik perempuan.

Dalam hal ini, masyarakat secara umum masih memiliki pandangan konvensional. Pandangan yang tercampur oleh kulur dan islam dan memunculkan peran perempuan sebagai pihak yang harus melaksanakan perintah laki-laki yang telah menjadi suaminya. Stigma perempuan sebagai pengurus rumah dan suami, mengakar kuat dalam masyarakat, sehingga perempuan yang bekerja diluar rumah tetap dituntut untuk melaksanakan kewajibannya sebagai istri dalam mengurus rumah dan suaminya. Kata "kewajiban" yang disematkan masyarakat menjadi pengikat bahwa perempuan tidak bisa lepas dari opini dan tuntutan peran domestik perempuan.

Kata mitra yang berusaha ditanamkan oleh penulis novel kedalam benak pembacanya sebagai sebuah sudut pandang baru mengenai peran perempuan. Kecenderungan penulis (mahdavi) adalah tetap menempatkan perempuan dengan urusan-urusan domestik tetapi dalam posisi yang equal, sehingga keputusan dan sikap yang diambil oleh perempuan sebagai istri (untuk urusan rumah tangganya) harus dihargai dan bahkan dipatuhi oleh suami.

Masyarakat modern saat ini memiliki pandangan yang beragam mengenai peran perempuan terutama dalam sosial dan politik. Perkembangan saat ini memperlihatkan bagaimana perempuan mampu menapaki karir yang sangat tinggi tanpa perbedaan dengan laki-laki. Apresiasi yang tinggi juga diperlihatkan oleh masyarakat terhadap perempuan yang berhasil menduduki jabatan tinggi dan bersanding dengan laki-laki tanpa perbedaan. Walaupun kemudian, apresiasi ini tidak lantas mengubah secara otomatis peran domestik perempuan atau menghilangkannya. Masyarakat masih melihat bahwa, karir tinggi yang dimiliki 
oleh seorang perempuan (istri) tidak akan ada artinya apabila rumah tangganya tidak terurus dengan baik.

Keempat, Hak pendidikan dan politik bagi perempuan dalam Islam sebagai representasi nilai kesetaraan laki-laki dan perempuan. Novel ini memperlihatkan perempuan dalam Islam memiliki hak dalam mendapatkan pendidikan dan juga hak untuk berpolitik ini merupakan bukti bahwa Islam sangat tidak mengekang hak dari perempuan, bahkan terlihat sangat adil, penggambaran ini merupakan implikasi dari maraknya penggambaran tentang perempuan dalam Islam yang selama ini diibaratkan sebagai perempuan yang terkekang dan harus menuruti lakilaki.

\section{Tabel 4. Hak Pendidikan dan Politik Bagi Perempuan}

\begin{tabular}{cl}
\hline Teks & Lale melanjutkan setelah memantau perhatian Charlotte. "Islam hadir \\
& dengan membawa harapan bagi tegaknya keadilan. Perempuan bukan lagi \\
& dianggap sebagai benda, tapi lebih jauh. Ia adalah mitra kaum lelaki. \\
& Perempuan telah menjadi subjek hukum. Rasulullah bersabda, menuntut \\
& ilmu adalah kewajiban bagi setiap muslim dan muslimah. Ini bukti bahwa \\
& perempuan memiliki hak untuk mencari ilmu dan kesempatan meraih \\
& pendidikan yang sama dengan kaum laki-laki. "Kemudian Allah berfirman \\
& dalam Alqur'an. Bismillabirrahmanirrabim. Hai Nabi, apabila datang \\
& kepadamu perempuan-perempuan yang beriman untuk mengadakan janji \\
& setia, bahwa mereka tidak akan mempersekutukan sesuatu pun dengan \\
& allah, tidak akan mencuri, tidak akan berzina, tidak akan membunuh anak- \\
& anaknya, tidak akan berbuat dusta yang mereka ada-adakan antara tangan \\
& dan kaki mereka dan tidak akan mendurhakaimu dalam urusan yang baik, \\
& maka terimalah janji setia mereka dan mohonkanlah ampunan kepada \\
& Allah untuk mereka. Sungguh Allah Maha Pengampun lagi Maha \\
& Penyayang. Ayat tersebut menjadi bukti perempuan dalam islam benar- \\
& benar telah menjadi subjek hukum dan dapat menentukan pilihannya \\
& sendiri. Mereka memiliki hak dasar politik." \\
Perempuan memiliki hak untuk mencari ilmu, perempuan dalam islam \\
benar-benar telah menjadi subjek hukum dan dapat menentukan \\
pilihannya sendiri. Mereka memiliki hak dasar politik \\
Denotasiam tidak memandang adanya perbedaan antara hak laki-laki dan \\
Makna \\
Konotasi \\
Perempuan dalam mendapatkan pendidikan dan ikut berpartisipasi dalam \\
politik \\
Perempuan dalam masyarakat Indonesia bebas memenuhi kebutuhan \\
pendidikannya baik secara formal maupun informal. Untuk hak politik pun \\
demikian. Perempuan bebas menjadi pemimpin daerah, instansi, ataupun \\
perusahaan swasta dan pemerintah.
\end{tabular}

Konstruksi penulis novel yang dapat dilihat pada tabel 4 merupakan kelanjutan pada konstruksi yang terlihat pada tabel sebelumnya. Setelah konstruksi tentang keutamaan perempuan dan kesetaraan peremuan dan laki-laki pada dimensi identitas perempuan muslim (hijab), domestik rumah tangga dan hubungan antara laki-laki dan perempuan, maka konstruksi berikutnya menyentuh pada dimnsi kehidupan sosial. Dalam tabel 4 penulis mengkonstruksi pemikiran 
tentang kesetaraan laki-laki dan perempuan dalam pendidikan dan politik. Teks yang menunjukkan tentang hal tersebut memiliki makna tentang kesamaan keutamaaan peempuan dalam berperan pada kehidupan sosial dengan laki-laki.

\section{Mitos tentang Posisi Perempuan Muslim dan Pemikiran Islam Moderat}

Mitos dalam representasi perempuan muslim pada novel Ratu yang Bersujud adalah pertemuan antara pembicaraan yang telah menjadi realitas di masyarakat dengan berbaga ide dan pemahaman tentang bagaimana Islam memposisikan perempuan. Novel Ratu yang Bersujud menjadi cermin sekaligus koreksi terhadap berbagai pandangan mengenai perempuan dalam Islam.

Stigma yang muncul ditengah masyarakat modern adalah stigma yang menggambarkan Islam sebagai hal yang konservatif dan cenderung memposisikan perempuan sebagai mahluk yang dibatasi dan dikekang. Pengekangan itu muncul melalui berbagai isu antara lain hijab dan poligami. Novel Ratu yang Bersujud mengetengahkan lahirnya mitos baru yang muncul belakangan di tengah pembicaraan masyarakat sebagai wajah baru Islam yang moderat.

Perkembangan pembicaraan di tengah masyarakat yang mengaitkan antara posisi perempuan dan Islam tentu tidak terlepas dari perkembangan varian pemikiran islam itu sendiri. Varian pemikiran Islam dapat dirujuk pada bagaimana pemahaman dan pengajaran Islam kemudian dilakukan dengan berbagai pendekatan yang berbeda. Ada pendekatan yang bersifat tekstual, memahami ajaran Islam berdasarkan sumber ajaran secara teks seperti yang tertulis. Adapula pendekatan tekstual yang mengaitkan kajian terhadap sumber ajaran dengan situasi realitas sosial yang terjadi dan menampilkan substansi dari teks tersebut. Kedua pendekatan ini menghasilkan pandangan yang berbeda tentang posisi perempuan dalam Islam.

Islam moderat adalah pemahaman tentang ajaran Islam yang berinterkasi dengan berbagai persoalan di era modern. Pemikiran ini merupakan wujud dari gerakan pembaharuan Islam era 70 -an yang mempertemukan antara metode studi Islam klasik dengan berbagai pemikiran modern yang menghasilkan suatu bentuk pemkiran Islam yang otentik dan kontekstual (Basya, 2005: 75). Pemikiran Islam moderat mempertemukan antara teks ajaran islam dengan konteks realitas dunia modern dalam suatu pemikiran yang rasional. Teologi kaum moderat adalah teologi yang rasional, kratif yang cocok dengan globalisasi (Hakim dan Mubarok, 1999: 195).

Novel Ratu yang Bersujud mengartikulasikan pandangan kelompok dalam memahami Islam secara kontekstual dengan lebih memperhatikan perubahan yang terjadi pada realitas perempuan di masyarakat. Mereka mengonstruksi ajaran Islam sebagai nilai yang memuliakan perempuan dan memposisikannya setara dengan laki-laki tanpa harus mempertentangkannya dengan teks-teks qur'an dan sunnah. Maka isu yang dimunculkan dalam pembicaraan kelompok ini adalah kesamaan hak pendidikan dan politik bagi laki-laki dan perempuan, kepemimpinan 
perempuan, dan kewajian berhijab sebagai upaya pemenuhan hak perempuan untuk mendapatkan perlindungan dan penghormatan.

Islam moderat dipahami sebagai pemikiran agama yang memposisikan berbagai aturan syar'i dan norma bukan hanya sebagai teks, tapi sesuatu yang memiliki tujuan, yaitu kemaslahatan manusia (Majelis Tarjih PP.Muhammadiyah, 2009). Ada kesalahpahaman sejumlah umat Islam tentang syari'at, ketika kritik terhadap pembatasan peran perempuan di wilayah publik diartikan sebagai penyerangan terhadap Islam (Basya, 2003). Maka segala aturan syari'at Islam tentang perempuan tidak boleh dilihat sebagai pengekangan terhadap perempuan, melainkan bentuk perlindungan dan pemuliaan martabat terhadap perempuan. Novel Ratu Yang Bersujud berupaya mengkonstruksi tujuan syari'at dar pandangan Islam tentang perempuan sebagai suatu mitos di masyarakat Islam moderat. Masyarakat Islam yang mengijinkan perempuan untuk memiliki pekerjaan di luar rumah, karir yang tinggi, bahkan menjadi seorang pemimpin. Sosok perempuan yang tidak lagi anti dengan hijab panjang, tren fashion, kosmetik dan media sosial. Pemikiran yang baru ini mengetengahkan versi humanis dalam pemikiran Islam yang kemudian juga menjadi versi mainstream di tengah masyarakat Indonesia.

\section{Representasi Perempuan Muslim dalam Siklis Konstruksi Realitas}

Terkait dengan konstruksi realitas agama, tulisan ini memaparkan siklis tiga siklus konstruksi realitas, yaitu, pertama konstruksi realitas agama Islam sebagai ajaran dan nilai. Kedua, konstruksi agama Islam sebagai institusi atau sistem. Ketiga, konstruksi ajaran agama Islam sebagai identitas kelompok. Konstruksi realitas agama sebagai ajaran terjadi ketika para pelaku atau individu berinteraksi dengan informasi atau sumber ajaran yang menyampaikan makna atau tujuan dari agama (Nurjuman, 2006).

Pada putaran konstruksi kedua, agama dikonstruksi sebagai institusi (Nurjuman, 2006) yang mengatur dan mengawasi para pemeluknya dengan hukum dan norma. Agama seringkali muncul dalam bahasa halal, haram, wajib, sunnah, makruh dan sebagainya. Maka pada masa konstruksi ini pembahasan tentang hijab disandarkan dengan kewajiban yang ditimpakan kepada perempuan. Kepatuhan isteri kepada suami dikonstruksi sebagai ikatan kewajiban yang berpahala jika dilaksanakan dan berdosa jika dilanggar. Hal ini merupakan konstruksi yang terbangun dari interaksi antara nilai-nilai yang telah ada pada siklus konstruksi sebelumnya dengan realitas berkembangnya komunitas umat Islam yang kemudian mewujud dalam suatu tatanan dan pranata sosial yang kemudian disepakati bersama oleh masyarakat.

Representasi perempuan muslim yang hadir pada periode konstruksi ini adalah tentang bagaimana perempuan muslim diletakan pada aturan-aturan dan norma Islam yang mengatur tentang perempuan. Perempuan muslim adalah objek yang dikenai hak dan kewajiban. Perempuan muslim yang ideal dan taat 
direpresentasikan dengan kepatuhannya mengenakan hijab, kesetiaannya mengurusi urusan rumah tangga, kesetiannya melaksanakan perannya sebagai mitra laki-laki, serta peran lainnya dalam kehidupan sosial. Kesemua representasi itu hadir dalam kerangka pelaksanaan norma dalam struktur pranata Islam.

Konstruksi yang terakhir adalah konstruksi agama Islam sebagai identitas. Pada fase ini, keterlibatan atau internalisasi masyarakat Islam dalam melaksanakan ajaran agama lebih dekat sebagai wujud keterikatan mereka dengan ajaran Islam atau bahkan hanya keterikatan tentang simbol-simbol ajaran Islam. Pengamalan perempuan muslim berjilbab adalah bentuk identifikasi diri mereka sebagai bagian dari kelompok muslim.

Konstruksi ini lahir dari interaksi yang terjadi antara norma-norma yang ada dalam sistem pranata masyarakat Islam dengan realitas simbolisasi ekspresi keberagamaan dalam kehidupan sehari-hari. Ketika individu yang terikat dengan ajaran Islam mencoba menginternalisasikan ajaran Islam baik secara murni sebagai ajaran maupun hanya sebagai kepatuhan terhadap norma, maka internalisasi itu mewujud dalam bentuk ekspresi yang terkait dengan identitas dirinya sebagai bagian dari kelompok Islam. Ketika seorang individu mengenakan jilbab sebagai ajaran dan norma, maka pemakaian jilbab itu juga kemudian menjadi ekspresi identitas dirinya sebagai muslimah.

Dalam kajian konstruksi realitas sosial, salah satu bagian penting dalam tahap konstruksi adalah objektivasi. Individu dalam masyarakat melakukan objektivasi terhadap produk sosial, baik penciptanya maupun individu lain (Bungin, 2008). Objektivasi adalah pertemuan antar indivdiu dalam masayarakat baik langsung maupun tidak (melalui media) yang dari interkasi tersebut meunculkan suatu kesadaan bersama yang disebut dengan realitas ojektif. Pemahaman tentang Islam baik sebagai nilai, norma maupun identitas kelompokmerupakan suatu objektivasi yang dihaskan dari interaksi yang menghasilkan suatu realitas objektif.Hal terpenting dalam objektivasi adalah pembuatan signifikansi, yakni pembuatan tanda-tanda (Bungin, 2008: 17). Sebuah wilayah penandaan (Signifikansi) dapat menjembatani wilayah- wilayah kenyataan, dapat didefinisikan sebagai sebuah simbol, dan modus linguistic dengan apa transenden seperti itu dicapai, dapat dinamakan bahasa simbol (Berger dalam Bungin, 2008: 17). Maka tanda, simbol dan bahasa menjadi bagian penting yang memastikan terbangunnya realitas objektif dalam masyarakat. Tanda, simbol dan bahasa menjamin adanya jembatan interkasi dalam masyarakat untuk membangun suatu realitas

Objektivasi yang menjadi realitas objektif dalam masyarakat harus dijembatani dengan berbagai tanda dan simbol, maka realitas objektif tentang agama sebagai suatu kelompok harus disimbolisasikan. Hal yang sama juga berlaku dengan realitas objektif tentang pandangan Islam mengenai perempuan. Hal tersebutpun harus dijembatani dengan suatu simbolisasi.

Representasi perempuan muslim yang dihadirkan pada konstruksi ini 
berupa simbol-simbol yang mewakili identitas perempuan muslim. Perempuan muslim digambarkan sebagai perempuan berhijab, sehingga tiap perempuan muslim merasa lengkap keanggotaannya sebagai muslimah ketika dia mengenakan hijab. Seorang perempuan muslim akan menjadi sempurna identitas keilsalammnaya ketika dia menampilkan simbol-simbol yang menghadirkan nilai dan norma Islam tentang perempuan.

\section{Konstruksi Islam sebagai Simbol Identitas melalui Representasi Perempuan Muslim}

Pembahasan tentang siklis konstruksi realitas agama merupakan suatu landasan bagi pembahasan representasi perempuan muslim sebagai alat atau cara mengkonstruksi Islam sebagai simbol identitas. Tiap putaran konstruksi realitas sosial selalu diidentifikasi dengan eksternalisasi, objektivasi dan internalisasi. Pembahasan tentang konstruksi tentang agama juga disandarkan kepada tiga tahapan tersebut.

Eksternalisasi adalah bagian penting dalam kehidupan individu dan menjadi bagian dari dunia sosiokultural (Bungin, 2007: 194). Pada pembentukan realitas sosial mengenai agama, eksternalisasi adalah proses pertemuan atau interaksi antara individu dengan berbagai produk pengetahuan tentang agama. Khususnya dalam tulisan ini adalah agama Islam. Tiap individu memiliki pengalaman berinterkasi dengan berbagai informasi dan sistem yang berlaku tentang ajaran agama yang mereka anut. Apa yang menjadi kewajiban, apa yang harus dilakukan dan apa yang tidak boleh dilakukan menurut ajaran agama telah menjadi informasi yang diserap oleh individu pada proses ini. Individu membangun suatu realitas subjektif berupa penyesuaian pemikiran dan sikap berdasarkan produk budaya yang mereka temui, baik sebagai anak yang tumbuh menjadi dewasa yang belajar dari orang tua dan ustaz di madrasah, atau pendatang yang baru masuk dalam suatu lingkungan yang menyesuaikan diri dengan paham masyarakat di lingkungan tersebut, atau orang yang baru menemukan ajaran agama Islam.

Representasi perempuan muslim pada novel Ratu yang Bersujud harus dipahami sebagai konstruksi yang diawali dengan eksternalisasi sang penulis. Eksternalisasi tersebut merupakan interaksi antara penulis dengan berbagai produk pemikiran Islam tentang perempuan dan realitas yang telah terjadi masyarakat, baik realitas tentang perempuan maupun realitas tentang konstruksi agama sebagai simbol identitas.

Interaksi pertama adalah pertemuan penulis dengan berbagai pemikiran Islam dan realitas di masyarakat terkait dengan Islam dan perempuan. Produk pemikiran Islam yang dimaksud adalah varian pemikiran Islam. Pemahaman terhadap ajaran agama telah membentuk sikap tertentu terhadap perempuan. Di satu sisi, ada interpretasi terhadap ajaran Islam yang menyatakan bahwa laki-laki merupakan pemimpin bagi perempuan, seringkali memunculkan tafsir yang memposisikan laki-laki lebih mulia daripada perempuan pada realitas dan interaksi 
sosial. Di sisi yang lain, ada juga pemahaman ajaran Islam yang tidak memosisikan laki-laki dan perempuan dalam posisi yang saling bertentangan dengan gerakan emansipasi dan kesadaran gender yang digelorakan. Pemahaman yang kedua ini mendorong para perempuan untuk terlibat bahkan berperan aktif dalam berbagai aktivitas sosial.

Baik paham yang konservatif mapuan yang moderat, pemahaman ajaran Islam telah mewarnai aktivitas perempuan di ranah sosial dengan adab-adab syar'i. Berbagai produk pemikiran Islam telah meletakkan panduan bagi wanita yang dapat menjaga diri berikut masyarakatnya, misalnya menutup aurat, larangan berduaan (berkhalwat), pemberian batas-batas ikhtilath dan hal lain yang terkait dengan keterlibatan wanita dalam aktivitas sosial.

Interaksi kedua adalah ketika penulis berhadapan dengan realitas perempuan Indonesia saat ini yang telah mengalami kemajuan. Bukan hanya berada pada posisi sebagai pengurus rumah tangga, tetapi juga menyatakan fungsinya dalam pembangunan dan dinamika masyarakat. Perempuan Indonesia tidak hanya bekerja di lingkungan rumah ataupun melayani suami dan anak, perempuan juga dapat berperan di dalam ranah politik, ekonomi dan sosial. Hal tersebut dapat dilihat dengan banyaknya perempuan di Indonesia yang bekarir di dunia kerja dan menempati posisi strategis di ranah sosial bahkan politik seperti menteri-menteri dan gubernur, serta adanya 30\% keterwakilan perempuan dalam parlemen.

Realitas tersebut merupakan hasil dari suatu proses konstruksi yang terjadi di masyarakat. Tiap individu, berinteraksi dengan berbagai produk budaya yang telah ada. Masyarakat telah bertemu dengan paparan isu kesertaan gender, emansipasi bahkan feminisme, yang kemudian mengadopsinya ke dalam pemikiran bahwa setiap manusia adalah "sama" apapun agama, suku, ras dan golongan. Begitupun jenis kelamin. Baik laki-laki maupun perempuan adalah "sama" dan harus dipandang dengan derajat yang sama. Keterlibatan pemikiran kesetaraan tersebut, menghasilkan produk budaya yang berbeda dari produk budaya dekade lalu. Islam berada dalam garda terdepan sebagai produk budaya yang mengalami perkembangan signifikan dan paling berpengaruh terhadap interaksi manusia di dunia secara keseluruhan.

Interaksi ketiga terjadi dengan realitas masyarakat modern, terutama barat yang memiliki anggapan dan dugaan tentang Islam yang meminggirkan perempuan. Dugaan dan anggapan ini merupakan hasil konstruksi tersendiri yang telah terjadi sebelumnya, yaitu konstuksi tentang benturan peradaban antara dunia barat dan dunia Islam. Konstruksi yang telah melewati rangkaian peristiwa sejarah yang panjang. Dimulai dengan rivalitas peradaban sejak abad pertengahan, perang salib sampai dengan isu terorisme dan ketidakadilan global, telah menjadi konstruksi yang berkesinambungan membangun realitas tentang perbenturan kultur barat dan Islam.

Hal lain yang dihadapi oleh sang penulis novel (Mahdavi) sebagai interaksi 
keempat dalam proses eksternalisasi, adalah adanya kecenderungan masyarakat modern kembali kepada hal-hal yang bersifat spiritual yang mewujud dalam bentuk tren simbolik (Ibrahim, 2011). Kegiatan keagamaan telah menjadi budaya populer. Pengajian telah berubah menjadi klub majelis ta'lim para sosialita, ziarah kubur telah berubah menjadi wisata religi, acara dakwah di televisi telah menjadi religiotaiment yang menggabungkan antara syi'ar Islam dan pengemasan entertaiment. Berbagai gejala tersebut telah menjadi realitas bahwa agama tidak hanya menjadi ajaran dan hukum, tapi telah menjadi tren yang membuat orang mengidentifikasikan dirinya dengan tren tersebut.

Realitas subjektif dalam proses eksternalisasi berlanjut pada proses pelembagaan yang membangun suatu realitas bersama baik dalam bentuk pemahaman/ideologi, norma dan simbol atau bahasa. Proses ini kemudian disebut dengan objektivasi Pada tahap ini, sebuah produk sosial berada pada proses institutsionalisasi (Bungin, 2007: 194) Pemahaman agama pada proses eksternalisasi bertemu dengan berbagai proses eksternalisasi lain yang ada di tengah masyarakat dan membangun kesadaran bersama yang kemdian diekspresikan dengan lembaga, norma dan simbol atau bahasa.

Esternalisasi sang penulis novel (Mahdavi) dengan berbagai realitas pengetahuan produk pemikiran Islam moderat, realitas kemajuan perempuan, stigma negatif barat atau dunia modern terhadap Islam (Hakim dan Mubarok, 1999) dan realitas masyarakat yang telah menjadikan kehidupan agama sebagai tren simbolik (Ibrahim, 2011), telah bertemu dengan proses eksternalisasi indivdu dan kelompok lain yang mengalami proses eksternalisasi yang sama. Hal itu kemudian membangun realitas bersama yang terlembagakan dengan satu konsep tentang identitas pemikiran Islam tentang perempuan. Identitas kelompok pandangan Islam di tengah era globalisasi dan modernisasi yang lebih memberikan peran bagi perempuan pada kehidupan sosial bermasyarakat dengan kesetaraan hak dan kewajiban antara laki-laki dan perempuan. Pelembagaan itu dilengkapi dengan signifikasi melalui simbol dan bahasa berupa teks-teks tentang hijab sebagai pemuliaan perempuan, kesamaan hak pendidikan dan politik bagi perempuan. Salah satu teks tersebut terdokumentasikan dalam novel Ratu yang Berujud.

Proses selanjutnya adalah internalisasi, yaitu tiap individu akan mencoba memosisikan peran masin-masing dalam masyarakat untuk menjalankan kesadaran yang dibangun dalam objektivasi. Proses internalisasi juga melibatkan identifikasi subjektif dengan peran dan norma-normanya yang sesuai (Bungin, 2008: 22). Masing-masing individu menafsirkan realitas objektif yang terbangun lalu mengambil peran yang diwujudkan dalam sikap dan perilaku. Tiap indivdiu mengidentifikasi dirinya sebagai bagian dari tren kehidupan beragama Islam yang modern. Penulis dan pembaca novel Ratu yang Bersujud akan mengidentifikasikan dirinya dengan berbagai teks novel yang mendeskripsikan dan membumikan berbagai konsep pemikiran Islam tentang hak - hak perempuan, peran perempuan 
dalam kehidupan sosial dan hijab sebagai pemuliaan perempuan.

Baik pada eksternalisasi, objektivasi dan internalisasi, interaksi antara masyarakat dan realitas dibarengi dengan adanya polarisasi ideologi kelompok baik kelompok pada internal muslim antara pemikiran yang konservatif dan moderat mapun antara peradaban Islam dan dunia barat. Konstruksi realitas Islam sebagai identitas dapat dilihat pada proses melembaganya pemikiran Islam moderat tentang perempuan sebagai sebagai simbol identitas. Hal ini mengemukakan bahwa munculnya pembahasaan dalam karya sastra tentang pemikiran Islam moderat tidak lepas dari pelembagaan arus pemikiran Islam moderat itu sendiri. Kehadiran novel Ratu yang Bersujud menjadi bagian dari tren simbolisasi keberagamaan yang muncul di tengah masyarakat, seperti kemunculan album lagi religi dan film-film religi, buku sastra dakwah juga muncul di tengah masyarakat yang mengobjektivasi agama sebagai simbol-simbol identitas.

Pemikiran Islam moderat tidak hanya menjadi pemikiran yang mewacana tapi telah menjadi internalisiasi tiap individu yang mengidentifikasikan dirinya sebagai bagian dari kelompok muslim moderat yang hidup di tengah dunia modern. Internalisasi tersebut telah menjadi tren keberagamaan yang menjadi identitas individu dan kelompoknya. Kesadaran bahwa hijab adalah simbol identitas perempuan muslim diinternalisasikan dengan pemakaian hijab para pembaca novel yang mengidentifikasi dirinya sebagai perempuan muslim. Sikap memerankan diri dalam rumah tangga merupakan internalisasi para pembaca terhadap simbol wanita Islam sebagai pemimpin rumah tangga. Demikian juga dalam hal peran perempuan sebagai mitra laki-laki dan isu implementasi kesamaan hak laki -laki dan perempuan dalam politik dan pendidikan.

\section{PENUTUP}

Hasil telaah ini menghasilkan kesimpulan bahwa Novel Ratu yang bersujud telah menghadirkan konsep Islam tentang perempuan muslim berupa perlindungan dan pemuliaan bagi perempuan, keutamaan peran perempuan dalam rumah tangga, perempuan sebagai mitra laki-laki, dan jesetaraan laki-laki dan perempuan.

Representasi konsep perempuan muslim merupakan bagian dari konstruksi Islam sebagai identitas kelompok. Konstruksi realitas itu terjadi sebagai hasil eksternalisasi berupa interaksi antara penulis dengan realitas varian pemikiran Islam, realitas kemajuan perempuan, realitas stigma negatif peradaban barat terhadap Islam, serta realitas tren simbolik kehidupan beragama. Selanjutnya hasil eksternalisasi tersebut menjadi realitas objektif berupa kesadaran dan pemahaman tentang identitas perempuan muslim yang kemudian disignifikasi dalam teks-teks novel. Internalisasi terjadi ketika masyarakat khususnya perempuan muslim, mengidentifikasi dirinya berdasarkan pemahaan mereka terhadap teks-teks yang dinarasikan dalam novel sebagai representasi perempuan muslim. 
Hasil temuan dan analisis ini dapat menjadi gambaran bagi proses intervensi dalam perubahan sosial, khususnya dalam intervensi yang berbingkai dakwah. Hasil penelitian ini menjadi gambaran tentang realitas tren di masyarakat yang menjadikan paham agama Islam tentang posisi perempuan sebagai representasi identitas, melauai produk budaya, berupa novel religi. Hal tersebut dapat menjadi pertimbangan bagi para pelaku dakwah untuk menggunakan produk budaya sebagai media atau sarana dalam menginternalisasikan berbagaipemikiran dalamI Islam menjadi suatu realitas yang dikonstruksi di tengah masyarakat. Realitas konstruksi agama sebagai simbol identitas akan menjadi masukan dalam perumusan strategi dakwah yang harus lebih dapat memainkan perannya dalam dunia simbolik dan praktik identitas.

Tulisan ini dapat dikembangkan dalam cara pandang yang berbeda ketika proses konstruksi realitas diposisikan sebagai sesuatu yang beririsan dengan kepentingan dan struktur. Kajian ekonomi politik dan kajian budaya kritis pada penelitian selanjutnya dapat memberikan penggambaran lebih lanjut tentang realitas ini.

\section{DAFTAR PUSTAKA}

Baran, J.S, \& Davis K. D. (2014). Mass Communication Theory: Foundations, Ferment, and Future, Teori Komunikasi Massa, Dasar, Pergolakan, dan Masa Depan. Jakarta: Salemba Humanika.

Basya, H. (2003). Perempuan dan Pemilu 2004, Rekonstruksi Teologi Islam Demi Keadilan Gender. Komunika (4), 42-47.

Basya, H. (2005). Melacak Jejak Ideologis Islam Moderat di Indonesia. Komunika, (9), 7378.

Berger, L. P., \& Luckmann, T. (1966). The Social Construction of Reality A Treatise in the Sociology of Knowledge. New York: Penguin Books.

Bungin, B. (2007). Sosiologi Komunikasi : Teori Paradigma dan Diskursus Teknologi Komunikasi di Masyarakat. Jakarta: Kencana.

Bungin, B. (2008). Konstruksi Sosial Media Massa. Kekuatan Pengarub Media Massa, Iklan Televisi \& Keputusan Konsumen Serta Kritik Terbadap Peter, L.Berger \& Thomas Luckmann. Jakarta: Kencana.

Burhani, A., N. (2001). Islam Dinamis, Menggugat Peran Agama Membongkar Doktrin yang Membatu. Jakarta: Kompas.

Hakim, A. A., \& Mubarok, J. (1999). Metodologi Studi Islam. Bandung: Remaja Rosdakarya

Hoed, B., H. (2011). Semiotik dan Dinamika Sosial Budaya. Depok:Komunitas Bambu

Ibrahim, I. S. (2011). Kritik Budaya Komunikasi, Budaya, Media Dan gaya Hidup dalam Proses Demokratisasi di Indonesia. Yogyakarta: Jalasutra.

Kusuma, B. T. (2017). Representasi Nilai Perempuan dalam Islam pada novel Ratu yang Bersujud. Skripsi. Program Studi Ilmu Komunikasi Universitas Sultan 
Ageng Tirtayasa, Serang.

Majelis Tarjih PP. Muhammadiyah. (2009). Himpunan Putusan Tariih. Yogyakarta : PP. Muhammadiyah.

Nashir, H. (2007). Gerakan Islam Syariat, Reproduksi Salafiyah Ideologis di Indonesia. Jakarta: PSAP.

Nurjuman, H. (2006). Konstruksi Media Islam tentang Pluralisme dalam Islam: Analisisterbadap Bingkai Media Sabili dan Syirah tentang Pluralisme dalam Islam di Indonesia. Tesis. Program Studi Magister Ilmu Komunikasi Universitas Indonesia, Jakarta.

Nurjuman, H., \& Sakinah, P. (2012). Kekuasaan Budaya Populer Religiotament dalam Pengemasan Program Acara Dakwah di Telvisi. Komunika, 9(4), 245-264. Jakarta : Program Studi Ilmu Komunikasi Uhamka.

Nurjuman, H., Wasingah, I., \& Sakinah, P. (2014). Kesalehan Simbolik Hijab Style Sebagai Budaya Konsumen. JRK: Jurnal Riset Komunikasi, 5(10), 16-35.

Saefullah, U. (2007). Kapita Selekta Komunikasi, Pendekatan Agama dan Budaya. Bandung: Simbiosa Rekatama Media. 